\title{
軸受用鋼における表面起点はくりと内部起点 はくりのころがり疲れ寿命
}

\author{
古 村 恭三郎*, 城田 伸一*, 平 川 清 ${ }^{*}$
}

\section{The Subsurface-initiated and Surface-initiated Rolling Fatigue \\ Life of Bearing Steels}

\author{
Kyozaburô Furumura, Shinichi Shirota \\ and Kiyoshi Hirakawa
}

\begin{abstract}
Synopsis
The mechanism of the asperity-contact-initiated fatigue was investigated in thrust type rolling fatigue tester. Microcracks appeared on the track surface at a considerably large number of cycles before the occurrence of the spalling failure. The electroslag remelted SUJ2 (AISI 52100) steel had a longer life than the degassed SUJ2 steel under conditions of predominating subsurface-initiated fatigue. However, it was found that this difference disappeared perfectly in the surface-initiated fatigue.

The same rolling fatigue behavior was found on six heats of carburized 4320 steel having different material cleanliness. In contrast to them, the influence of metallurgical characteristics of carburized steel was remarkable in the surface-initiated fatigue but not in the subsurface-initiated fatigue.
\end{abstract}

1. 緒䇾

ころがり疲れの研究において，表面を起点とするは くりと内部の欠陷を起点とするはくりがはっきりと区 別されるようになったことは，この分野の研究におけ る最近の著しい進歩である。 表面起点のはくりは潤滑条件が悪く相接する転動面 が油膜によって完全に分離されず，金属接触が生じる 場合に起こる(1) 。

したがって，あらさの山や条痕，ピットなどは局部 的な応力集中源となり易く，そこからクラックを発生 し，やがてはくりまでに成長するとみられている。 内部起点のはくりについても，やはりクラックの発

昭和50年 5 月 20 日受付

${ }^{*}$ 日本精工侏技術研究所
生源となるのは幅部におけける欠陥であり，非金属介在 物を第一に考えるべきであろう。

これまでころがり疲れに関する材料，材資面の研 究は数多く報告されているが，それらのころがり疲れ 寿命帮験におけるはくりが表面起点のものであるか， 内部起点のものであるかを区別して実験した例はまだ 数少ないようである4，6，7。

表面起点はくりと内部起点はくりではクラックの発 生伝ぱのメカニズムに相違があるであろらことは充分 想像されるので，この点を明確に区別しておかない と, 材料のころがり疲れ寿命の評価において誤まった 䊅論を引出す場合すあり得るであろ5。

このような観点から，材料のころがり疲れ寿命の評 価によく用いられているスラスト型寿命試験機におい て,クラックの起点をできるだけ明確に, 表面と内部 に限定し，それぞれの場合における材質ところがり疲 
Table 1. Specimens and endurance test data.

\begin{tabular}{|c|c|c|c|c|}
\hline Surface finishing & $\begin{array}{l}\text { Average } \\
\text { Roughnesss }\end{array}$ & $h_{0} / R$ & $\begin{array}{l}\text { Steel } \\
\text { Load }\end{array}$ & $\begin{array}{l}\text { SUJ2(52100) } \\
325 \mathrm{~kg}\end{array}$ \\
\hline $\begin{array}{l}\text { Grinding } \\
\text { Imperfect lapping }\end{array}$ & $\begin{array}{l}0.77 \mu \\
0.37\end{array}$ & $\begin{array}{l}0.08 \\
0.16\end{array}$ & $\begin{array}{l}\text { Max. Normal Hertz. Stress } \\
\text { Lubricant } \\
\text { Speed }\end{array}$ & $\begin{array}{l}500 \mathrm{~kg} / \mathrm{mm}^{2} \\
\text { No. } 60 \text { spindle oil } \\
1000 \mathrm{rpm}\end{array}$ \\
\hline $\begin{array}{l}\text { Polishing } \\
\text { Lapping }\end{array}$ & 0.09 & $\begin{array}{l}0.23 \\
0.67\end{array}$ & $\begin{array}{l}\text { Depth of max. alternating } \\
\text { shear stress } \\
\text { Operating temperature }\end{array}$ & $\begin{array}{l}0.110 \mathrm{~mm} \\
50 \sim 55^{\circ} \mathrm{C}\end{array}$ \\
\hline
\end{tabular}

れ寿命の関保について実験した結果を報告する。

\section{2. 表面起点はくりを生する条件}

\section{1 試䀦 条 件}

スラスト型寿命試験機に扎いて，表面起点はくりを 生ずる条件を知るためにTable 1 の条件で寿命試験を 行ない, 試験後に走行跡表面を光学顕微鏡下で観察し た。試験片は $60 \phi \times 20 \phi \times 7 \mathrm{~mm}$ 円板である。

試験片の表面仕上げを研削仕上げ，研削目残りのあ るラップ仕上げ，ベルト研摩仕上げ，ラップの 4 と拉

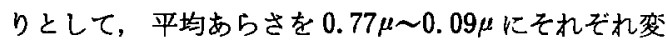
えてある。材料，熱処理はすべて同一である。（脱が スSUJ2材, $830^{\circ} \mathrm{C}$ 焼入れ， $170^{\circ} \mathrm{C}$ 焼もどし，かたさ $\mathrm{H}_{R}$ $\mathrm{C} 62 \sim 63)$

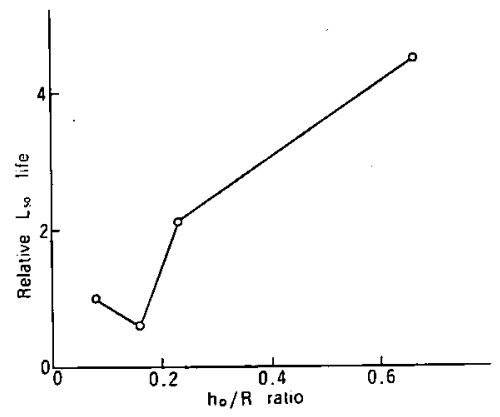

(a) As a function of $h_{0} / R$ ratio
潤滑油はすべて \#60スピンドル油であり，試験中の

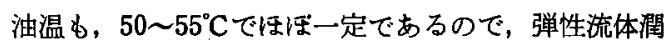
滑下の最小油膜厚さと合成あらさの比 $\mathrm{h}_{0} / \mathrm{R}$ はあらさ が大きい活ど小さくなる。hoは Chengの式8)によっ て計算した。

\section{2 試 験 結 果}

寿命試験結果を Table 2 拉よびFig. 1 に示す。 Fig. 1 (a)k示すよ $5 に, h_{0} / R$ の減少とともに寿命は 低下し, 最も寿命の長いラップ仕上げのグループに比 べて，研摩目残りのラッブ仕上げのグループは約 $1 / 8$ の寿命である。また，ラッブ仕上げのグルーブに比べ ると，それよりあらさの大きな他の 3 グルーブはい ずれも明白な 寿命の低下を示している。この結果は

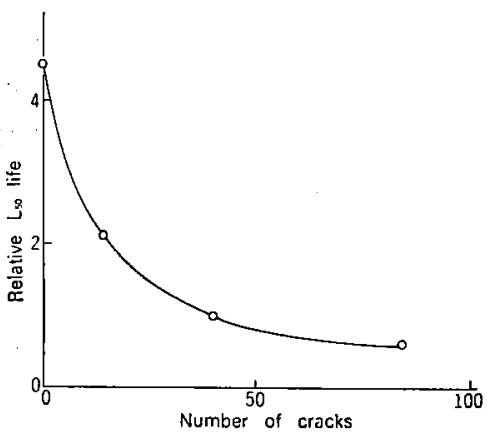

(b) As a function of number of cracks

Fig. 1. Fatigue life of SUJ 2 steel.

Table 2. Results of rolling fatigue test (1).

\begin{tabular}{|c|c|c|c|c|c|c|}
\hline \multirow{2}{*}{ Surface finish. } & \multirow{2}{*}{$\mathrm{h}_{0} / \mathrm{R}$} & \multirow{2}{*}{$\begin{array}{l}\text { Number } \\
\text { tested }\end{array}$} & \multirow{2}{*}{$\begin{array}{l}\text { Number } \\
\text { failed }\end{array}$} & \multicolumn{2}{|c|}{ Life, $10^{8}$ cycles } & \multirow{2}{*}{$\begin{array}{l}\text { Number } \\
\text { surface } \\
\text { cracks }\end{array}$} \\
\hline & & & & $\mathrm{L}_{10}$ & $\mathrm{~L}_{50}$ & \\
\hline Grinding & 0.08 & 14 & 10 & 1.36 & 2.95 & 40 \\
\hline Imperfect lapping & 0.16 & 13 & 13 & 0.80 & 1.71 & 84 \\
\hline Polishing & 0.23 & 15 & 13 & 2.10 & 6.10 & 14 \\
\hline Lapping & 0.67 & 12 & 10 & 5.12 & 13.47 & 0 \\
\hline
\end{tabular}


Danner ${ }^{8)} の$ 得た結果に類似している。

このよ 5 な寿命の低下が表面を起点としたクラック によってもたらされたものかどうか, 試験後に転劫面 を光学顕微鏡によって観察した。その結果 Photo. 1 に示すよ5な表面クラックが発生していることが判っ た。これらのクラックは澡漂研摩の条痕に平行しに発 生し，発達したものは条痕の方向とは関係なく複雑な 進展を示していた。樑さ方向には Photo. 2 のように 20〜 50 の角度をなして数十 $\mu$ の深さむで進展してい るむのを見出すことができた。

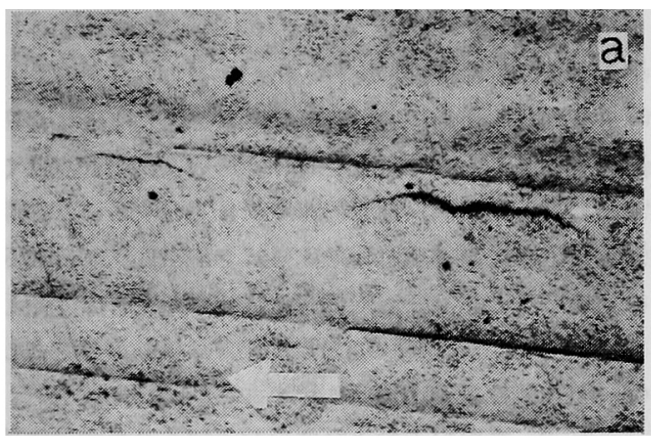

(a) Crack

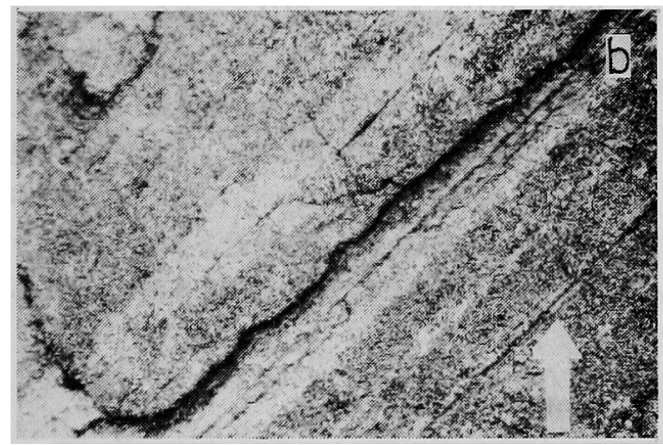

(b) Crack

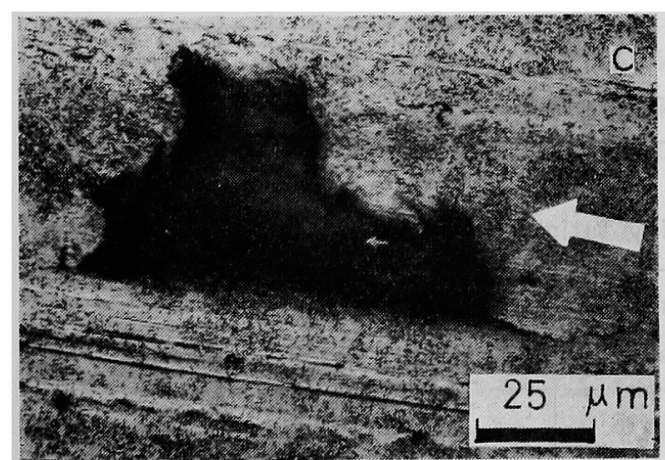

(c) Micro-spall

Photo. 1. Crack and micro-spall at grinding furrow.
1 試験片上に発生していたクラックの数を平均值で 示したのがTable 2 の最右欗である。ラップ仕上げで はまったく表面クラックが見られないが，他の三つの 仕上げのグルーブにはいずれも上述の特徽を有する表 面クラックが見られた。ここで注目されるのは，最す クラック発生数の多いグルーブが最むあらさの大きな 研削仕上げのグループではなくなり，そのちょ 5 ど半 分にあらさの山を削り落とした研削目残りラッブ仕上 げのグループであることである。

しかも，Fig. 1 (a)の $\mathrm{h}_{0} / \mathrm{R}$ と寿命の関係として整理 すると研削目残りラップのグループが一つたけけはずれ ていたのが同図(b)のよ5に，クラック発生数を横軸に とると、クラック数が多い汪ど寿命が低下するとい5 きれいな相関が得られる。このことは表面クラックの 発生した 3 グループの寿命がこれらのクラックによっ て支配されていること, つまり表面起点のはくりを生 じていることを示す一つの証拠とみなすことができ る。

さらに，研削仕上げと研削目残りのラップ仕上のグ ループでは，そのはくりの形態にはっきりした特徽が みられた。Photo. 3 に示すよ5に,これらのグループ のはくりの Leading Edge（玉が転がって来て最初 にはくりに出会う側）がそれらのすべてにおいて，研 摩の条痕に一致していることである。このことは先の

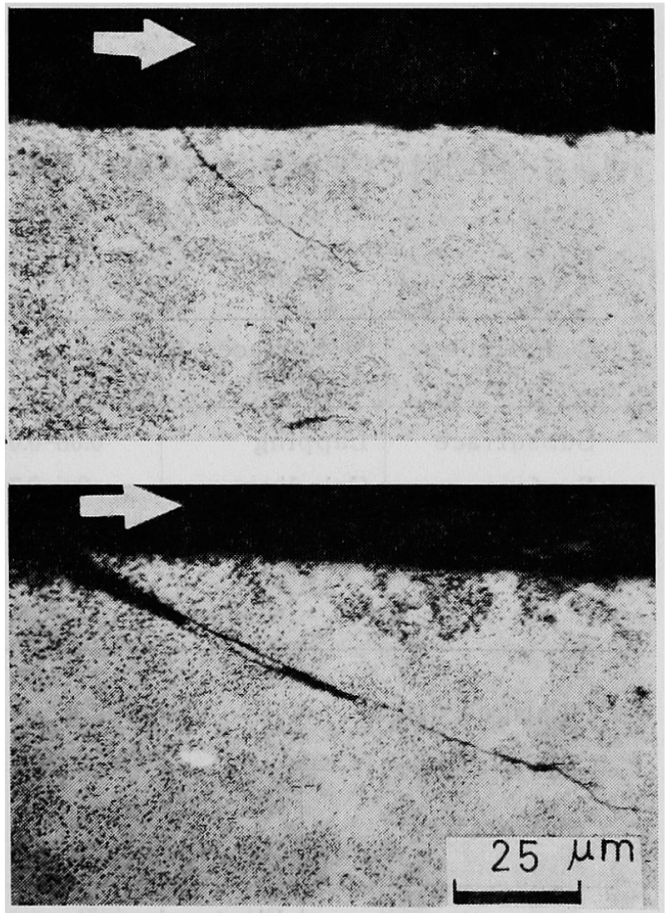

Photo. 2. Cross sectional view of crack. Arrow indicates rolling direction. 


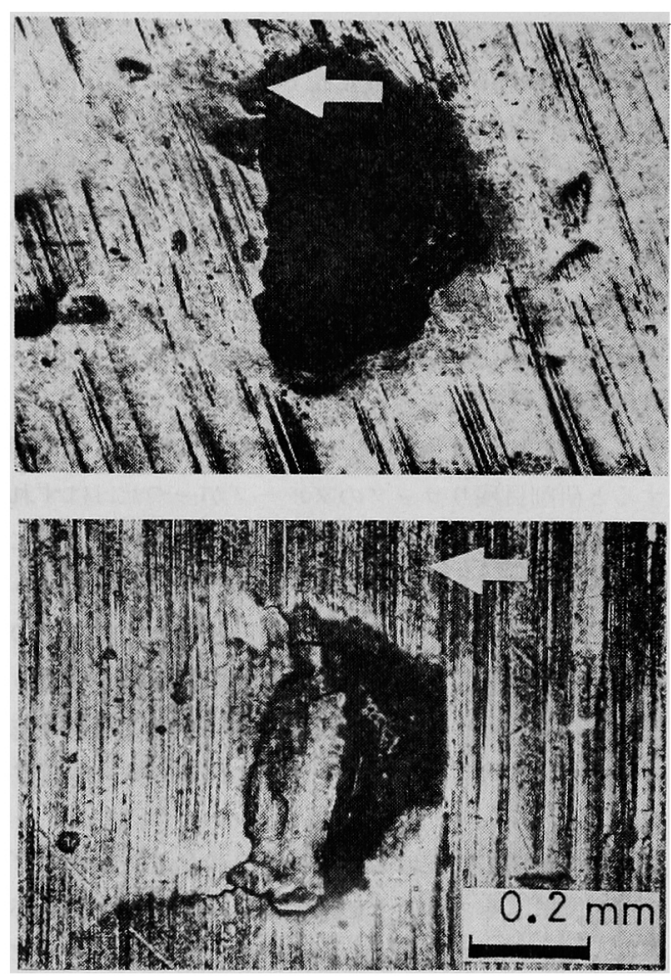

Photo. 3. Typical spall of asperityinitiated-fatigue.

クラックの観察において表面クラック研摩の条痕に沿 って発生していたことと考学合わせると，これらのク ラックのどれかが発達して，はくりに達したというこ とを示している。

ポリシング仕上げのグループはすべてのはくりにこ
のよ5な特幑が見られず, ラッブ仕上げのグルーブの はくりに似たものもあったので,このグループの寿命 はすべてが表面起点のはくり寿命を示すとはい劣な W。

最後にラップ仕上げグループでは表面クラックがみ られず，従来よくいわれてきた最大比ん断応力位固付 近の深さの内部を起点とするはくりとみられるが，内 部起点はくりであるという直接的な証拠を得ることは 当然のことであるが，困難なことである。

\section{3. 表面起点はくり寿命と内部起点はくり寿命の特 性}

\section{1 寿命試㹂条件}

2 章の結果から, 表面起点はくりの条件として, 研 摩仕上げグループの条件を選び，一方，内部起点はく りの条件としては，前章のラップ仕上げグルーブの閏 滑油をさらに高粘度井 180 のタービン油に变えて, $h_{0} / R$ の比を 2.5 とし, 一応内部起点はくりの条件と想定し て，以下の各種の材質に 関する 寿命試験の条件とし た。試験条件をTable 3 に示す。

\section{2 表面起点および内部起点はくり塞命試験結 果と考察}

(1) ESR・SUJ2 と脱ガス・SUJ 2 の寿命

Table 4 に示すよ 5 に，内部起点はくりの 場 合, ESR 材は脱ガス材の 2 倍以上の寿命であった。これ らの材料の酸素量はTable 5 に示すよ5に，むしろ眖 ガス材の方が少ない。したがって，ESR材の寿创が 増大する理由は酸化物系介在物の量よりる，その大き さ，形状などの相違に求めなければならないようであ

Table 3. Surface and subsurface fatigue test data.

\begin{tabular}{l|l|c|c|c|c}
\hline \multicolumn{1}{c}{$\begin{array}{c}\text { Fatigue } \\
\text { origin }\end{array}$} & \multicolumn{1}{|c|}{$\begin{array}{c}\text { Surface } \\
\text { finish }\end{array}$} & Roughness & Lubricant & $h_{0} / \mathrm{R}$ & $\begin{array}{c}\text { Max. Hertz. } \\
\text { stress }\end{array}$ \\
\hline $\begin{array}{l}\text { Subsurface } \\
\text { Surface }\end{array}$ & Lapping & $0.06-0.09$ & No. 180 Turbine oil & 2.5 & $500 \mathrm{~kg} / \mathrm{mm}^{2}$ \\
Grinding & $0.6-0.7$ & No. 60 Spindle oil & 0.09 & 500 & " \\
\hline
\end{tabular}

Table 4. Results of rolling fatigue test (2).

\begin{tabular}{|c|c|c|c|c|c|}
\hline \multirow{2}{*}{ Fatigue origin } & \multirow{2}{*}{ Material } & \multirow{2}{*}{$\begin{array}{l}\text { Number } \\
\text { tested }\end{array}$} & \multirow{2}{*}{$\begin{array}{l}\text { Number } \\
\text { failed }\end{array}$} & \multicolumn{2}{|c|}{ Life, $10^{6}$ cycles } \\
\hline & & & & $\mathrm{L}_{10}$ & $L_{50}$ \\
\hline \multirow{2}{*}{ Subsurface } & Electroslag & 15 & 15 & 8.0 & 37 \\
\hline & Vacuum degas & 12 & 12 & 3.2 & 17 \\
\hline \multirow{2}{*}{ Surface } & Electroslag & 10 & 10 & 1.3 & 2.6 \\
\hline & Vacuum degas & 10 & 10 & 1.4 & 3.3 \\
\hline
\end{tabular}


Table 5. Chemical compositions and metallurgical characteristics.

\begin{tabular}{l|c|c|c|c|c|c|c|c|c}
\hline \multirow{2}{*}{ Material } & \multicolumn{7}{|c|}{ wt. \% } & $\begin{array}{c}\text { Hardness } \\
\text { (Rc) }\end{array}$ & $\begin{array}{c}\text { Retained } \\
\text { austenite }\end{array}$ \\
\cline { 2 - 9 } & $\mathrm{C}$ & $\mathrm{Si}$ & $\mathrm{Mn}$ & $\mathrm{P}$ & $\mathrm{S}$ & $\mathrm{Cr}$ & $\mathrm{O}$ & $\mathbf{8}$ & $8 \%$ \\
Electroslag & 1.01 & 0.22 & 0.42 & 0.016 & 0.009 & 1.37 & 0.0020 & 62 & $8 \%$ \\
Vacuum degas & 1.00 & 0.28 & 0.44 & 0.014 & 0.009 & 1.38 & 0.0015 & 62 & 8 \\
\hline
\end{tabular}

る。

一方, 表面起点はくりの場合には, Table 4 の下欄 に示したよらに，ESR材と脱ガス材の寿命差はまった くみられなくなる。

このことは，ESR材あるいはVAR材もそうであろ うが，材料の波浄度をよく知って，ころがり疲れ寿命 が増大するとい5現象は内部起点のはくりを生ずる条 件の場合であって, 表面にクラックを生じてはくりを 生ずるような場合には効果をもたないといらことを示 していると考えられる。

（2）溶解チャージの異なる漫炭鋼の寿命

つぎTable 6に示すよ5な脱ガスした浸炭鋼 SA E $4320 \mathrm{H}$ 材の溶解チャージの異なる 6 チャージについ て同様の寿命試験を行った。いずれも径 $65 \mathrm{~mm}$ の棒材
から試験片を削り出した。

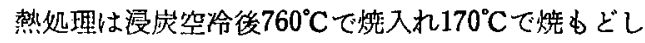
した。これら 6 チャージの試験片はTable 6 および 7 に示すよ 5 に, 化学成分，ミク口の組織，かたさ，C\% などいずれも卮とんど差がみられない。介在物につい てはA，Bグルーブが Sulphideが少なく，C，Dグ ルーブに多いこと。 D, F グループが B typeが多い ことが特徴であるが，定量的評洒は難しい。

寿命試験結果をTable 8 にワイブル分布を Fig. 2 に示す。

内部起点はくりの場合, それぞれ化学成分, 材質な ど非常に類似したものでありなから，きわめて大きな 寿命のばらつきを有することが判る。

最も長寿命のCグルーブに比較して，最も短寿命の

Table 6. Chemical compositions of SAE 4320 steel.

(wt. \%)

\begin{tabular}{c|c|c|c|c|c|c|c|c|c}
\hline Heat & $\mathrm{C}$ & $\mathrm{Si}$ & $\mathrm{Mn}$ & $\mathrm{P}$ & $\mathrm{S}$ & $\mathrm{Ni}$ & $\mathrm{Cr}$ & $\mathrm{Mo}$ & $\mathrm{O}$ \\
\hline $\mathrm{A}$ & 0.17 & 0.29 & 0.65 & 0.011 & 0.002 & 1.62 & 0.47 & 0.22 & 0.0022 \\
$\mathrm{~B}$ & 0.20 & 0.23 & 0.53 & 0.007 & 0.004 & 1.65 & 0.40 & 0.21 & 0.0026 \\
$\mathrm{C}$ & 0.20 & 0.27 & 0.51 & 0.010 & 0.016 & 1.78 & 0.45 & 0.22 & 0.0015 \\
$\mathrm{D}$ & 0.19 & 0.25 & 0.53 & 0.017 & 0.019 & 1.75 & 0.50 & 0.24 & 0.0021 \\
$\mathrm{E}$ & 0.20 & 0.27 & 0.55 & 0.010 & 0.007 & 1.65 & 0.45 & 0.21 & 0.0014 \\
$\mathrm{~F}$ & 0.18 & 0.27 & 0.61 & 0.008 & 0.004 & 1.68 & 0.45 & 0.22 & 0.0021 \\
\hline
\end{tabular}

Table 7. Inclusion evaluation and metallurgical charasteristics of carburized 4320 steel.

\begin{tabular}{|c|c|c|c|c|c|c|c|c|c|c|c|c|}
\hline \multirow{3}{*}{ Heat } & \multicolumn{8}{|c|}{ ASTM-D method } & \multirow{3}{*}{$\begin{array}{c}\text { Hardness } \\
\text { D.P. N. }\end{array}$} & \multirow{3}{*}{$\begin{array}{l}\text { Retained } \\
\text { austenite }\end{array}$} & \multirow{2}{*}{\multicolumn{2}{|c|}{ Surface C\% }} \\
\hline & \multicolumn{2}{|c|}{ A } & \multicolumn{2}{|c|}{ B } & \multicolumn{2}{|c|}{$\mathrm{C}$} & \multicolumn{2}{|c|}{$\mathrm{D}$} & & & & \\
\hline & $\mathrm{T}$ & $\mathrm{H}$ & $\mathrm{T}$ & $\mathrm{H}$ & $\mathbf{T}$ & $\mathbf{H}$ & $\mathrm{T}$ & $\mathbf{H}$ & & & Total & Matrix \\
\hline A & 0.5 & 0 & 1.0 & 0 & 1.0 & 0 & 1.0 & 1.0 & 803 & $7 \%$ & 0.91 & 0.59 \\
\hline B & 0.5 & 0 & 1.0 & 0 & 0 & 0 & 1.0 & 0.5 & 793 & 6 & 0.88 & 0.61 \\
\hline C & 1.0 & 1.0 & 1.0 & 0 & 0.5 & 0 & 1.0 & 0.5 & 806 & 7 & 0.85 & 0.62 \\
\hline $\mathrm{D}$ & 1.0 & 1.0 & 2.0 & 2.0 & 1.0 & 1.0 & 1.0 & 0.5 & 810 & 8 & 0.87 & 0.58 \\
\hline $\mathrm{E}$ & 1.0 & 0 & 2.5 & 0 & 1.0 & 0 & 1.0 & 0.5 & 803 & 7 & 0.88 & 0.58 \\
\hline $\mathrm{F}$ & 1.0 & 0 & 2.5 & 1.0 & 1.0 & 1.0 & 1.0 & 0.5 & 810 & 8 & 0.88 & 0.58 \\
\hline
\end{tabular}


Table 8. Results of rolling fatigue test.

\begin{tabular}{|c|c|c|c|c|c|}
\hline \multirow{2}{*}{ Fatigue origin } & \multirow{2}{*}{ Heat } & \multirow{2}{*}{ Number tested } & \multirow{2}{*}{ Number failed } & \multicolumn{2}{|c|}{ Life $10^{\circ}$ cycles } \\
\hline & & & & $\mathrm{L}_{10}$ & $L_{50}$ \\
\hline \multirow{6}{*}{ Subsurface } & A & 14 & 14 & 4.4 & 31 \\
\hline & B & 14 & 12 & 10.2 & 41 \\
\hline & $\mathrm{C}$ & 14 & 7 & 40.5 & 126 \\
\hline & $\mathrm{D}$ & 14 & 11 & 10.1 & 45 \\
\hline & $\mathbf{E}$ & 14 & 14 & 16.0 & 70 \\
\hline & $\mathrm{F}$ & 14 & 10 & 8.9 & 29 \\
\hline \multirow{6}{*}{ Surface } & A & 12 & 12 & 0.35 & 0.73 \\
\hline & B & 12 & 12 & 0.56 & 0.84 \\
\hline & $\mathrm{C}$ & 12 & 12 & 0.61 & 0.96 \\
\hline & $\mathrm{D}$ & 13 & 13 & 0.56 & 0.81 \\
\hline & $\mathrm{E}$ & 14 & 14 & 0.64 & 0.84 \\
\hline & $\mathbf{F}$ & 14 & 14 & 0.57 & 0.88 \\
\hline
\end{tabular}

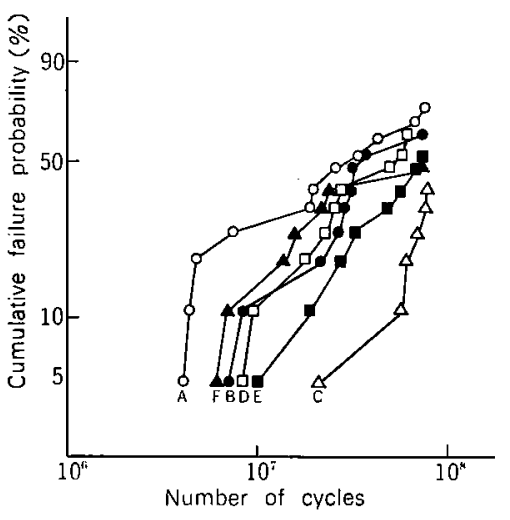

Fig. 2. Rolling-contact fatigue of six heats of SAE 4320 steel.

A グループは，10\%破損寿命で約 $1 / 9 ， 50 \%$ 破損寿命 で1/4ときわめて大きな差がある。

ころが渡れ寿命に影響を与える材料的因子に関し ては，これまで多くの研究がされているが，ての中 で最も大きな影響を有するのは非金属介在物であると いえるだらう。

介在物と寿命の関係についてはJohnsonと Sewell 10)が広範な 実歌の結果を報告している。彼らによれ ばアルミナ，シリケートなど酸化物系介在物はころが り疲れ寿命に有害であるが，硫化物系介在物は寿命を 低下させないかあるいはむしろ寿命を増加させる効果 をるつとされている。岡本，仕幸11)るスラスト型寿 命により同じ結論を得ている。

さらに，Enekes ${ }^{12)}$ は酸化物系介在物を酸素量で
置き換光，硫化物系介在物を S\%でおきがて，各種 の溶解材のころがり疲れ寿命が 鋼中酸素量と $\mathrm{S} \%$ 比O/Sとの関係でよく整理されることを示した。

すなわち，O/Sが減少（Oが減少または Sが増加） するにつれてころがり疲れ寿命が増大すると述べてい る。

そこで，前述した 6 チャージの材料の寿命差の最も 大きな要因として，われわれは非金属介在物に着目し た。

この場合, 直接介在物の評価を定量化することはき わめて困難なことなので, Enekes と同じく0\%と \%で代用し，O/S比と寿命の相関をみた。

Fig. 3 に示すよ 5 に，内部起点はくりの場合， O/S 比と寿命に $10 \%$ 寿命， 50\%寿命ともかなりよい

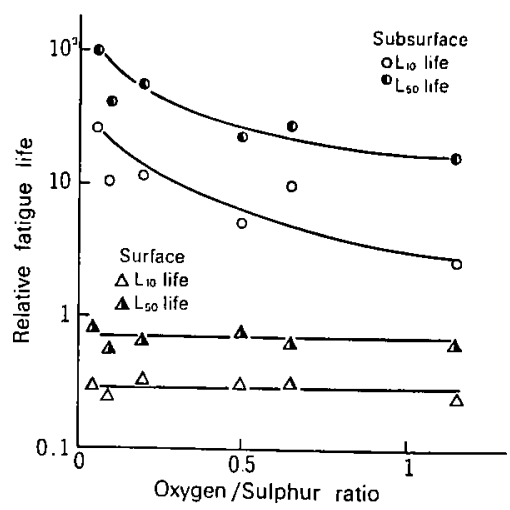

Fig. 3. Correlation between $\mathrm{O} / \mathrm{S}$ ratio and endurance life. 
相関がられる。 $0 / \mathrm{S}$ 比は単純に O\%を S \%で除し たものであるから，O 1 ppmと S 1 ppmが同じオー ダで寿命に影響することをすでに仮定していることに なる。実際にはSulpherは酸素活ど微量で影響するこ とは考えられないので，Fig. 3 の横軸は本来なら， $\mathrm{O} / \mathrm{S}$ 比でなくfunc. $(\mathrm{O}, \mathrm{S})$ となるのが正しいので ある5。

しかし，O/S比でかなりよく寿命が整理されるこ とは，内部起点はくりが非金属介在物に強く影響され ることを示するのと考えられる。

内部起点はくりでは大きな寿命のばらつきがみられ たか，表面起点はくりでは，Fig. 3 に示されている よ5に活とんど差がなく，注漂一定值を示す。

したがって, 内部起点から表面起点に寿命を左右す るクラックの起点が変ることによって，内部起点はく りで最す長寿命であったCグループは $1 / 100$ に寿命が 低下してしまうのに対して，短寿命のAグループは $1 / 20$ 程度の寿命低下となり, 寿命の減少率では長寿命 のもの潘ど著しいということになる。

Fig. 3 のよ 5 に, 表面起点はくり寿命が $0 / \mathrm{S}$ 比と 相関をもたないことからも，この試験においても，ク ラックが介在物と無関係に表面に批いて発生している ことを侐付けているものとみられる。

(3) 焼入温度の異なる浸炭鋼の寿命

つぎに前節の試験で用いたF グルーブのSAE 4320 銅を素材として，2 次焼入温度を 3 通りに変えた試験 グループについて，同様の寿命試験を行なった。

浸炭空冷後， 2 次焼入温度をTable 9 のよ 5 に780, $820,900^{\circ} \mathrm{C}$ の 3 種類に変えた。

この結果, 試験片の材質は同表中に示したよ5に, それぞれかたさ，残留オーステナイト量，マトリック スC\%などが変化している。

この3グループについて, 内部起点㧍よび表面起点 のはくりを生じさせる寿命試験を行なった結果,

Fig. 4 の結果が得られた。

Fig. 4 のプロットはそれぞれ14個の試験グループ

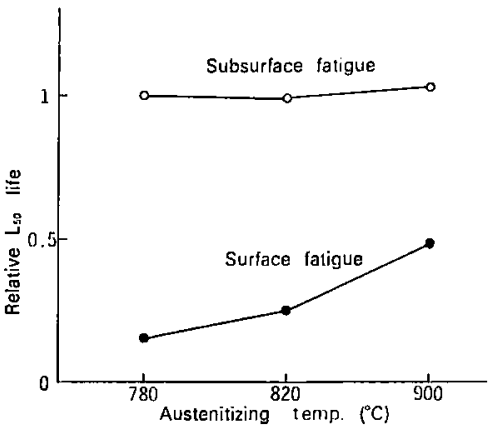

Fig. 4. Endurature life of carburized SAE 4320 steel as a function of austenitizing temperature.

の50\%破損寿命である。かたさグループごとに異なる 場合，スラスト型寿命試験機では試験片の走行跡の Groovingか問題になる。

この場合，それぞれの Groovingの曲率の平均を求 め，Hertz接触圧力低下を算出した後，压力の 9 乗に 寿命が反比例するという関保式を用いて補正した。

Fig. 4 亿おいては，溶解ナャージによる寿命の変動 とは逆に，内部起点はくり寿命は 2 次焼入温度にほと んぞ関係を有せず，表面起点はくり寿命が焼入温度の 増大と共にやや増加する傾向がみられる。

しかし，その増加は $780^{\circ} \mathrm{C}$ 焼入れに対して900 $\mathrm{C}$ 焼入 れのグルーブが約 2 倍程度であって，顕著な差ではな い。したがって，表面起点はくりにおいても2 次焼入 温度の影響は実用上の範囲では余り大きな影響を及漂 さないといってよいだろう。

スラスト型寿命試験においては，しばしば特異な組 織变化がみられる(8)，14)。

すでに坪田ら ${ }^{15)}$ は本報と同じ接触圧力下の 寿命試 験を行なった試験片に樹脂状の組織変化が発生したこ とを報告している。

われわれの実験においても Photo. 4 (a)〜(c) に 示すよ 5な白色の樹脂状のきわめて大きな組織変化が 見出された。

Table 9. Metallurgical characteristics of different heat treatment groups carburized 4320 steel (Heat A).

\begin{tabular}{c|c|c|c|c|c|c}
\hline \multirow{2}{*}{$\begin{array}{c}\text { Carburized } \\
\text { at }\end{array}$} & $\begin{array}{c}\text { Austenitized } \\
\text { at }\end{array}$ & \multicolumn{2}{|c|}{ Surface C $\%$} & Hardness & $\begin{array}{c}\text { Retained } \\
\text { austenite }\end{array}$ & $\begin{array}{c}\text { Retained } \\
\text { cementite }\end{array}$ \\
\cline { 3 - 6 } & Total & Matrix & & 780 & $16 \%$ & $6.5 \%$ \\
$925^{\circ} \mathrm{C}$ & $780^{\circ} \mathrm{C}$ & 1.05 & 0.63 & 758 & 25 & 3.5 \\
& 820 & 1.05 & 0.83 & 758 & 0 \\
\hline
\end{tabular}




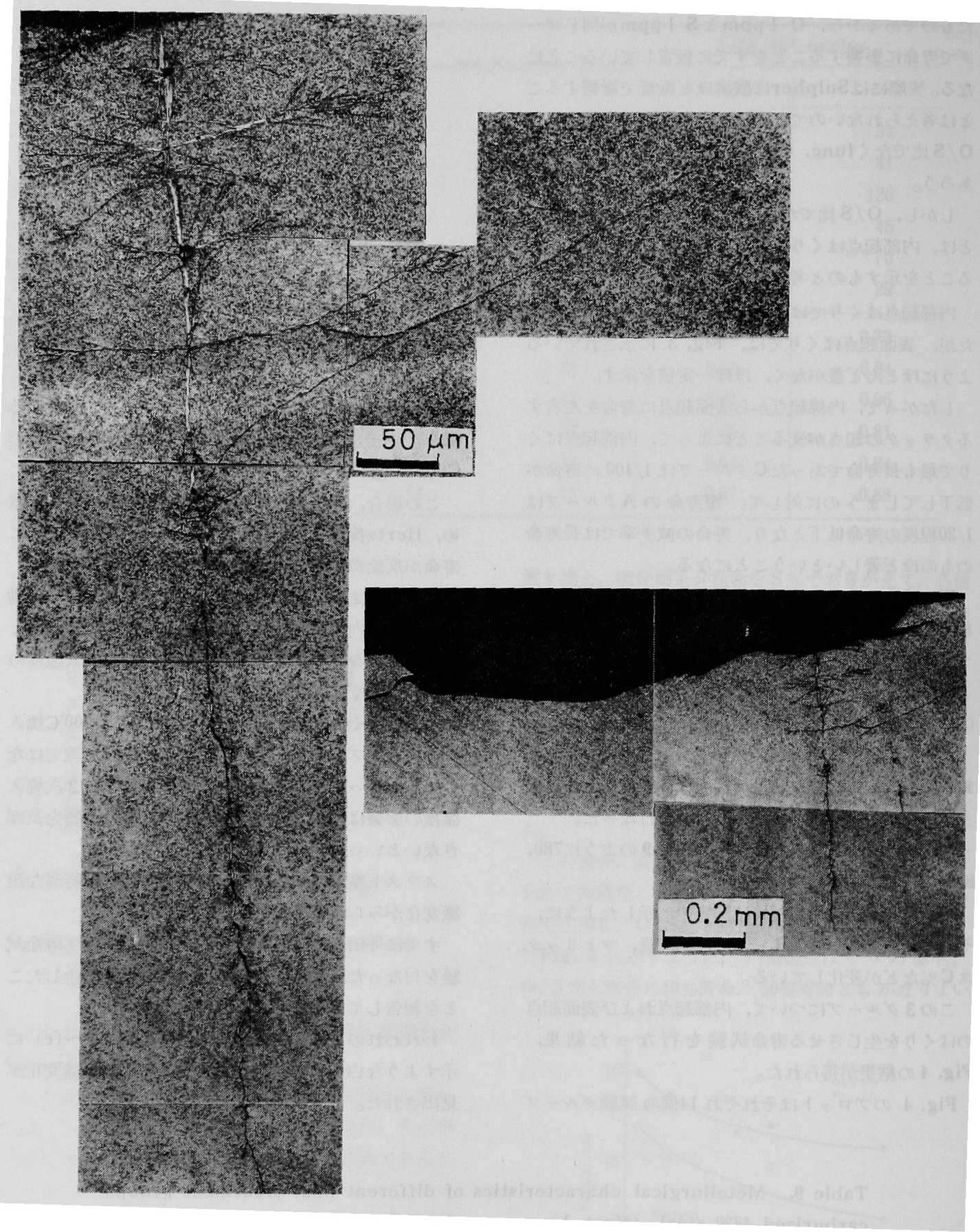



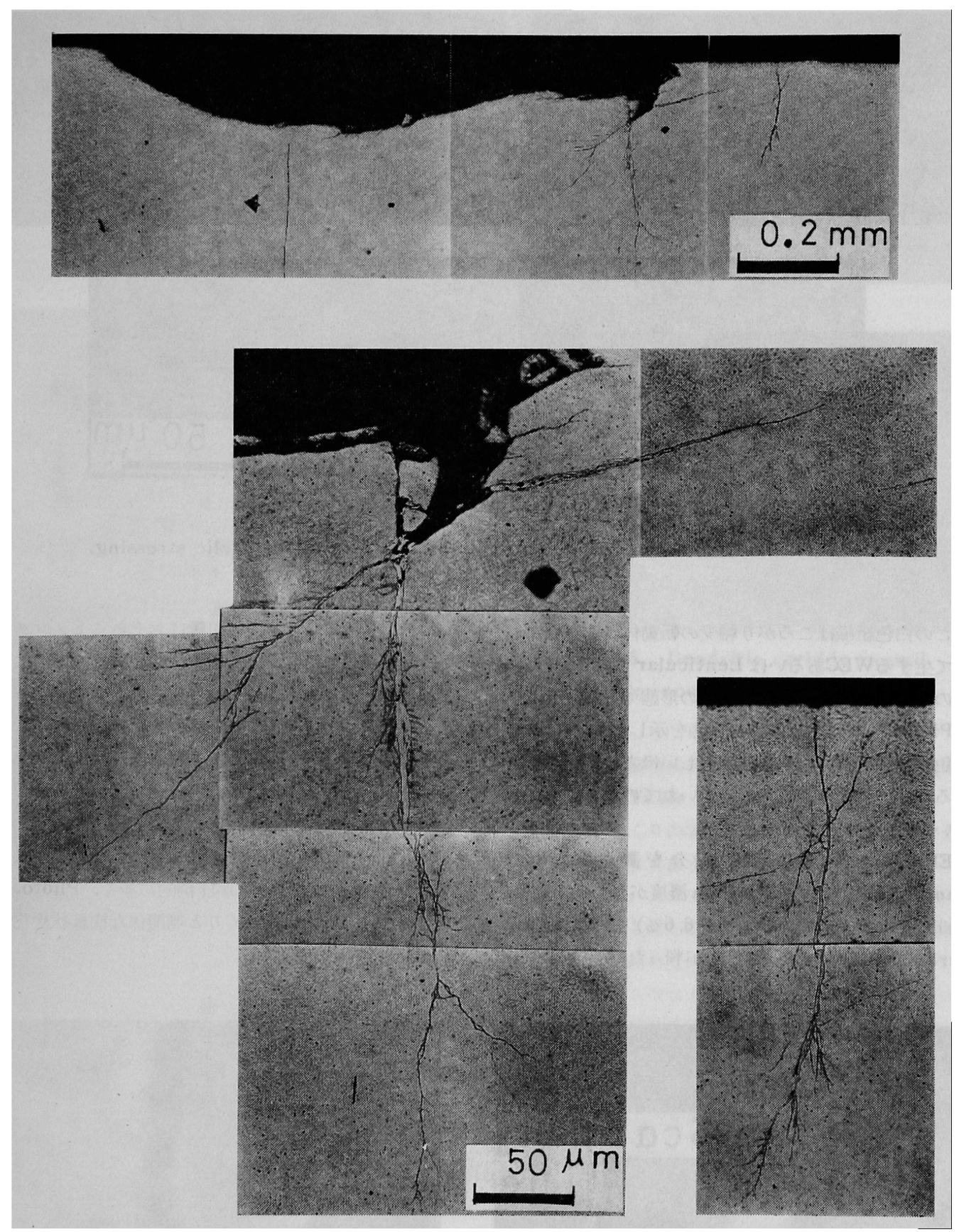

4-(b) Cross sectional view 

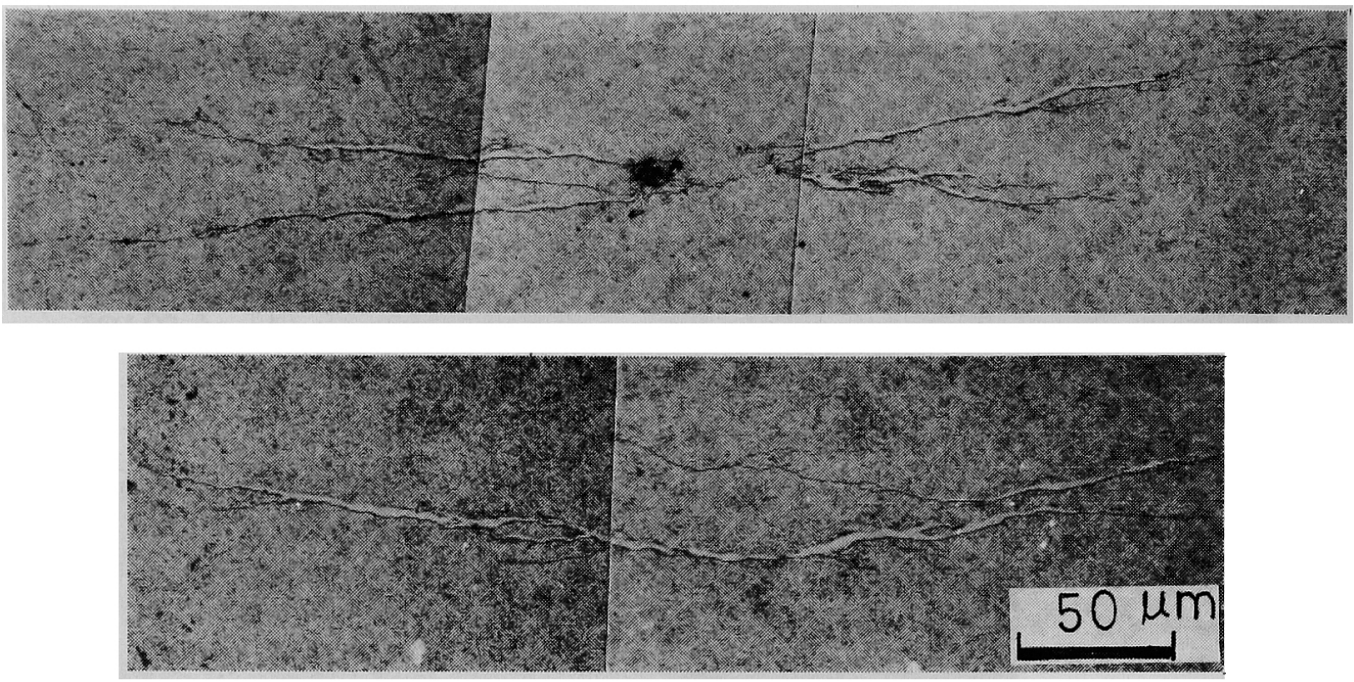

4 -(c) Horizontal view

Photo. 4. "Dendritic carbide" at the spall as a result of cyclic stressing.

この白色組織はころがり軸受の転動体，軌道輪にお いて生ずるWECあるいは Lenticular Carbide とは その形態を異にしており，独特の形態である。

Photo. 4 (c)に水平断面の形態を示したよ5に,この 白色組織は走行跡の幅と汪深等しい汪どの広がりで, ころがり方向と活深直角に，ついたてのよに発生し ているとみられる。

EPMA でこの白色組織の成分を調べた結果， Photo. 5に示すよ5にCarbon 濃度がきわめて高く， 活活セメンタイト中のC \% (約 $6.6 \%$ ） と同じ程度に Carbonが濃縮されていることが判った。

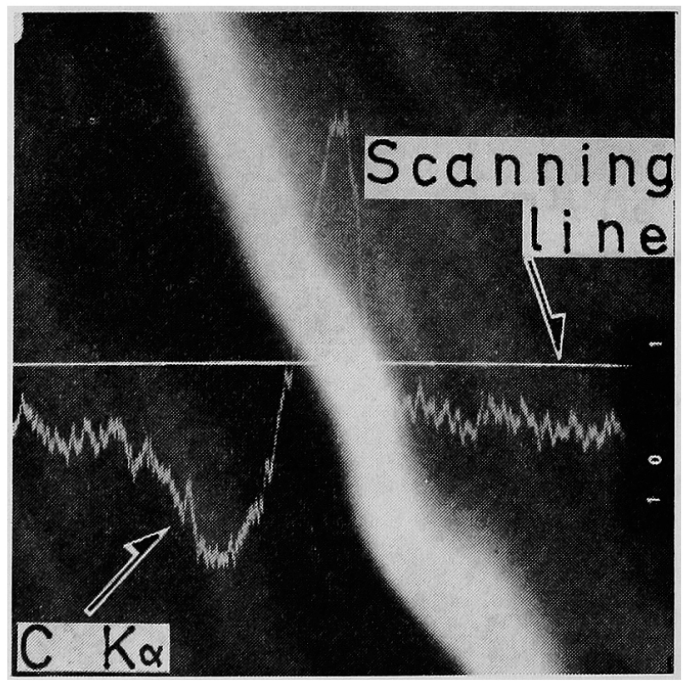

したがって，この白色組織はおそらくセメンタイト に似た組成であり，仮に樹枝状炭化物と呼ぶのにふさ わしいものであると考えられる。

この樹枝状岸化物は Photo.6に示すよ5に，しば しば地すず状のアルミナ系介在物を連結する形で形成 されていることから，やはり酸化物系介在物を起点と して発生, 生長するむのとみられる。

しかもこの樹枝状炭化物は走行跡上の分布では，は くり部に存在することが圧倒的に多く, Photo. 4 (b) の右に見えるようなはくりと無関係な樹枝状炭化物は 比輅的発生率が小さい。

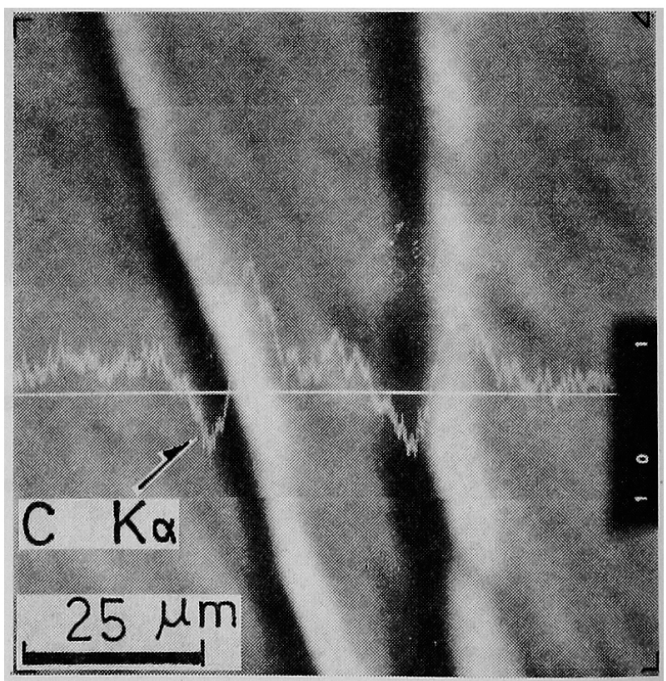

Photo. 5. Analysis on carbon content of dendritic carbide in EPMA. 

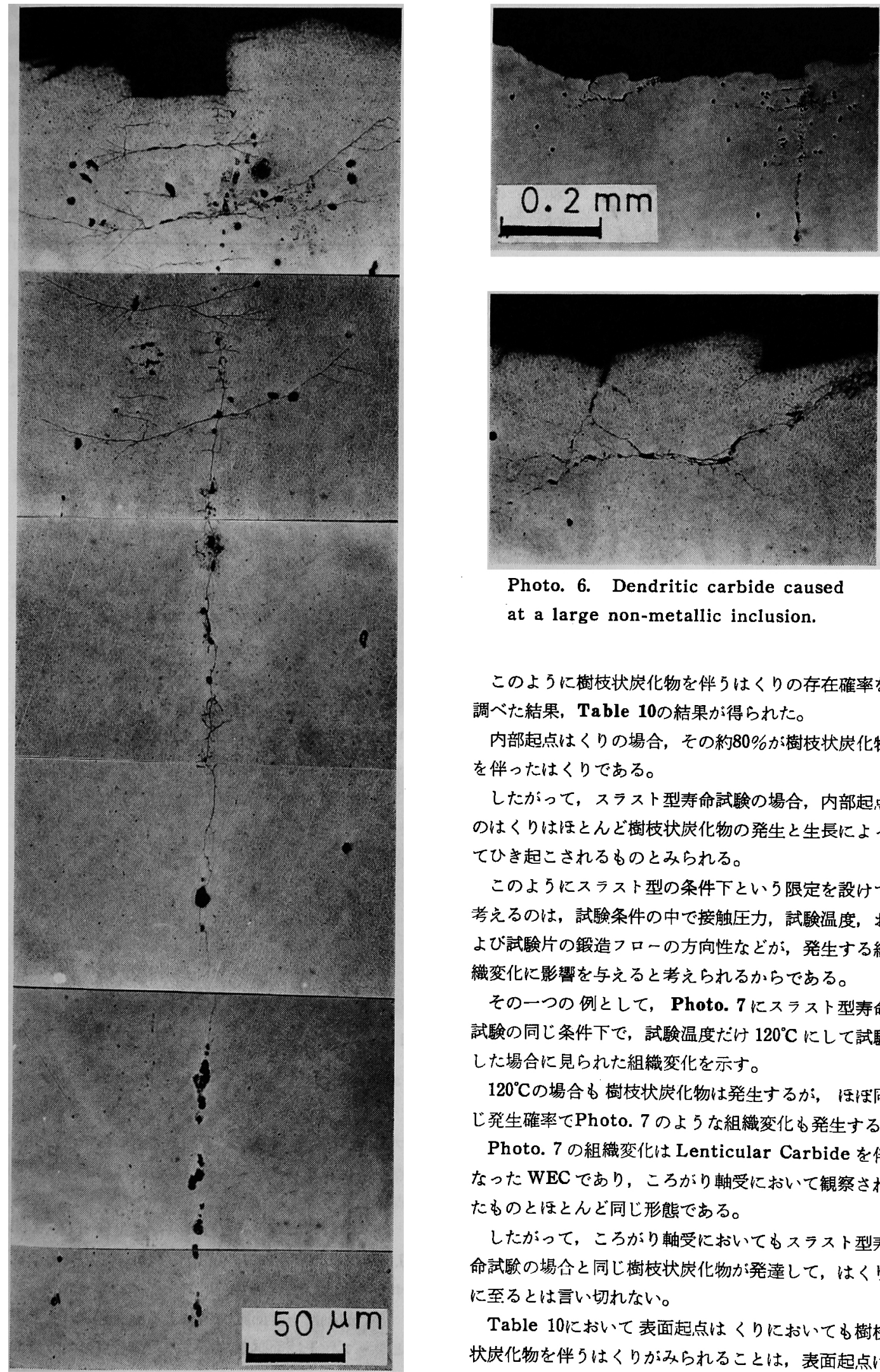

Photo. 6. Dendritic carbide caused at a large non-metallic inclusion.

このよ5に樹枝状炭化物を伴 5はくりの存在確率を 調べた結果, Table 100結果が得られた。

内部起点はくりの場合，その約 $80 \%$ が樹枝状炭化物 を伴ったはくりである。

したがって，スラスト型寿命試験の場合, 内部起点 のはくりはほとんど樹枝状炭化物の発生と生長によっ てひき起こされるものとみられる。

このよらにスラスト型の条件下とい5限定を設けて 考えるのは，試騟条件の中で接触圧力，試験温度，お よび試験片の鍛造フローの方向性などが, 発生する組 織変化に影響を与えると考えられるからである。

その一つの例として, Photo. 7 にスラスト型寿命

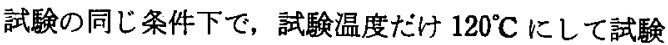
した場合に見られた組織変化を示す。

$120^{\circ} \mathrm{C}$ の場合も樹枝状炭化物は発生するか， 活济同 じ発生確率でPhoto. 7 のよ 5な組織変化も発生する。

Photo. 7 の組織変化は Lenticular Carbide を伴 なった WECでありころがり軸受において観察され たものとほとんど同じ形態である。

したがって、ころがり軸受においてもスラスト型寿 命試駼の埸合と同じ樹枝状炭化物が発達して、はくり に至るとは言い切れない。

Table 10において表面起点はくりにおいても樹枝 状炭化物を伴 5はくりがみられることは，表面起点は 
Table 10. Number of spalls with dendritic carbide.

\begin{tabular}{l|c|c|c}
\hline Fatigue origin & Austenitized at & $\begin{array}{l}\text { Number } \\
\text { spall observed }\end{array}$ & $\begin{array}{l}\text { Number spall with } \\
\text { dendritic carbide }\end{array}$ \\
\hline \multirow{2}{*}{ Subsurface } & $780^{\circ} \mathrm{C}$ & 14 & 12 \\
& 900 & 14 & 11 \\
\hline \multirow{2}{*}{ Surface } & 780 & 10 & 2 \\
& 900 & 10 & 1 \\
\hline
\end{tabular}

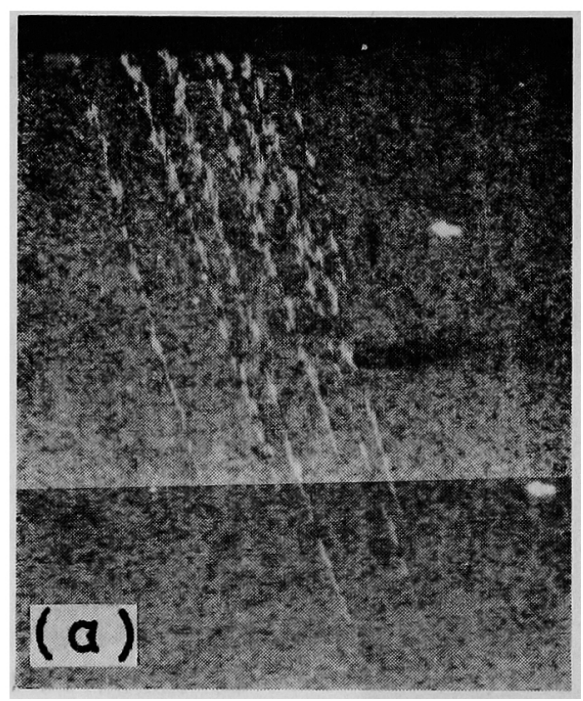

(a) Cross sectional view

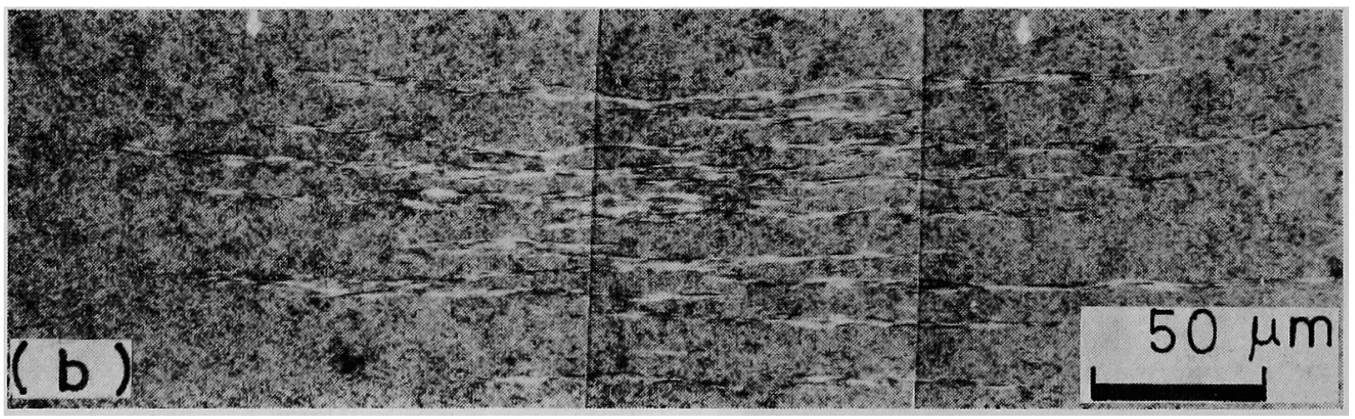

(b) Horizontal view

Photo. 7. Microstructural alternation caused at $120^{\circ} \mathrm{C}$. (White etching constituent)

くり寿命試験か完全に表面からだけクラックを発生さ せる条件下で行われなかったといらことを示している と考光るべきであろ5。しかし，その大半は樹枝状炭 化物が発生する以前にすでにはくりしており，われわ れの目的は一応達成しているものと考えられる。
4. ま め
（1）研削仕上げ面，ヘルト研摩面，研削目残り

プ仕上げ面の試験片はいずれも表面にあらさの山を起 点とするクラックを発生し，その伝ぱによって表面起 点のはくりを生じた。

(2) これらのグルーブはラッブ仕上げ面 $\left(\mathrm{R}_{\mathrm{a}} 0.06 \sim\right.$ $0.09 \mu \mathrm{m})$ のグルーブに比ベて数分の 1 の寿命に低下 する。

（3）研削仕上げ面試験片による表面起点はくり寿命 とラップ仕上げ面試験片による内部起点はくり寿命試 
験を行なったところ, ESR材と脱ガス材，および浸炭 鎆SAE 4320 の溶解チャージの異なる材料など, 非金 属介在物の相荤がみられるグループの寿命は, 内部起 点はくりの場合に明らかに差が現われるか，表面起点 はくりの場合はまったく差がるられなかった。

（4）浸岸鎆 2 次焼入温度の影響は内部起点はくりの 場合は汪とんどみられず，表面起点はくりの場合に， 焼入温度の増大に伴いやや寿命が增加する㑯向がら れた。

（5）主として内部起点はくりの場合樹枝状炭化物と みられる白色の組織変化が観察された。

樹枝状炭化物は介在物を起点として発生し，樹枝状 炭化物か発澾するとその界面からクラックが生じて, はくりに至るものと考えられる。

\section{（文献）}

1) Tallian, T.E., McCool, J.I. and Chiu, Y.P.; "An Engineering Model of Spalling Fatigue Failure in Rolling Contact", Wear, 17 (1971), 433.

2) Littmann, W.E. and Widner, R.L.; "Propagation of Contact Fatigue from Surface and Subsurface Origins", Trans. ASME, D, 88 (1966), 624.

3) Martin, J.A. and Eberhardt, A.D.; "Identification of Potential Failure Nuclei in Rolling Contact Fatigue", Trans. ASME, D, 89 (1967), 932.

4) Littmann, W.E., Widner, R.L. and Wolfe, J.O.; "Tthe Role of Lubrication in Propagation of Contact Fatigue Cracks", Trans. ASME, F, 90 (1968).

5) Sugino, K., Nagumo, M. and Miyamoto, K.; "Failure Process of Bearing Steel in Rolling Contact Fatigue", Trans. ISIJ., 11 (1971), 9.
6) Sheehan, J.P. and Howes, M.A.H.; "The Effect of Case Carbon Content and Heat Treatment on the Pitting Fatigue of 8620 Steel", SAE paper, No. 720268 (1972).

7) Vaessen, G.H.G. and De Gee, A.W.J.; "Rolling Contact Fatigue of Maraging Steels of Different Production History", EHL, 1972 Symp. IME, C7/72.

8) Cheng, H. S.; Trans. ASME, F, 94 (1972), 35.

9) Danner, C.H.; "Fatigue Life of Tapered Roller Bearings under Minimal Lubricant Films", ASLE Trans., 13 (1970), 241.

10) Johnson, R.F. and Sewell, J.F.; "The Bearing Properties of $1 \% \mathrm{C}-\mathrm{Cr}$ Steel as Influenced by Steelmaking Practice", JISI, 196 (1960), 414.

11）岡本，仕幸; 軸受鋼のころがり疲学寿命におよ䚾 す非金属介在物の影響 製鉄研究，(1971）273, 108

12) Enekes, S.; "Effects of Some Metallurgical Characteristics on the Fatigue Life of Bearing Steels", JISI, 210 (1972), 83.

13) Martin, J.A., Borgese, S.F. and Eberhardt, A.D.; "Microstructural Alternations of Rolling Bearing Steel Undergoing Cyclic Stressing", Trans. ASME, D, 88 (1966), 555.

14) Buchwald, J. and Heckel, R.W.; "An Annalysis of Microstructural Changes in 52100 Steel Bearings during Cyclic Stressing", Trans. ASM, 61 (1968), 750.

15）坪田, 結城, ほ隹; 転動疲労組織について 鉄々鐗，57（1971）4，S 206 